Article

\title{
Dirty Water, Muddied Politics: Hybridisation of Local and National Opposition to Kumtor Mine, Kyrgyzstan
}

\author{
Joseph Horrocks-Taylor ${ }^{(D)}$ \\ School of Geography, University of Oxford, Oxford OX1 3QY, UK; joseph.horrocks-taylor@st-hildas.ox.ac.uk;
} Tel.: +44-(0)-770-259-8604

Received: 6 March 2018; Accepted: 31 March 2018; Published: 3 April 2018

check for updates

\begin{abstract}
From a Mongolian 'super mine' to China's One Belt One Road, rapid infrastructural development is reforging Central Asia as an economic pivot of the future. Such development offers enticing economic benefits, but threatens fragile environments and local livelihoods. Due to the weakness of the state, the emphasis will be on citizens to hold developers accountable to their social and environmental pledges. Reports of political elites influencing the demands of popular protests call into question the ability of citizens to fulfil this function. This paper examines protest authenticity in Kyrgyzstan, focusing on an environmental social movement against Kumtor gold mine. We trace the emergence and evolution of the social movement, identifying the flexible discursive and scalar strategies it uses to achieve emphasis of the local level and relevance on the national scale. The discussion focuses on how national political saliency may incentivise elite involvement with social movements. This involvement can mask the local demands of the social movement, fixing the environmental problem as a national issue. It is crucial to understand the scalar dynamics of elite-protest interaction if Central Asian civil society is to hold future infrastructural developments to account.
\end{abstract}

Keywords: Central Asia; Kyrgyzstan; infrastructure; environment; mining; social movements; protest; environmental justice; subversive clientelism

\section{Introduction}

In 1904, Halford Mackinder identified Central Asia as the geographic "pivot of history" [1] (p. 1). Today, this region is being reforged as an economic pivot of the future. The world's longest gas pipeline and two of the world's largest open-pit mines have been constructed, and the world's tallest dam is on track to come online in 2018 [2-4]. These developments are reliant on foreign capital looking to exploit the mineral reserves and geostrategic positioning of the region. However, these large infrastructure projects can have myriad environmental impacts, including land degradation, biodiversity loss, dust generation, water pollution and water depletion, which threaten the health and livelihoods of communities living in Central Asia's steppe drylands [5,6]. The significant risks and rewards of development projects mean that the extractive sector in the region is a 'battleground', with local, national and international actors all fighting for their interests [7]. This is a dynamic interface, with discourses constantly being rejected, recycled and reproduced to suit the shifting strategies of this diverse set of actors. Here, we examine how the changing landscape of this 'battleground' influences the evolution of a local social movement against Kumtor gold mine in Kyrgyzstan. While Kumtor demonstrates how existing infrastructure in Central Asia is heavily contested and has largely failed to live up to local expectations, future developments like China's $\$ 1$ trillion One Belt, One Road (OBOR) project continue to progress apace [8]. It is essential to understand how specific discourses enable or 
prevent citizen protest from holding infrastructure development to account in Central Asia when faced with "repression from a state-capital symbiosis" [9] (p. 16).

While there are a variety of definitions of Central Asia, this paper will use the broader delimitation which included "Afghanistan, northeastern Iran, Pakistan, northern India, western China, Mongolia and the former Soviet Central Asian republics" [10] (p. 24). The mineral resources of this region are "a geologist's paradise", but "a pain" to develop [11,12]. The landforms of the region are restrictive of infrastructural development, from the KyzylKum and KaraKum deserts of the west to the Tian Shan and Pamir mountains of the southeast. This landscape can "thwart and crush infrastructure" [8] (p. 62). However, much of the blame for slow development has been attributed to the weakness of the state. The role of the state has been the focus of much of the expanding literature on infrastructure projects in Central Asia. Scholars have identified infrastructure as a tool of nation-building $[4,13,14]$, a question of sovereignty [15-17] and a source of rent-seeking [18]. From this state-centric viewpoint, the emergence of environmental social movements opposing infrastructural developments in Central Asia occurs due to the absence of the state. The failure of the state to meet society's basic economic needs allows elites to capture community support by providing material or symbolic investments $[19,20]$. Elites can then use 'public' protests as "weapons of the wealthy" to achieve their private political goals [19] (p. 1). Alternatively, the contrast between the financial strength of foreign investors and the perceived weakness of the state can lead to questions of sovereignty, with the potential to trigger social movements demanding resource nationalisation [15].

In these theoretical discourses, the local scale is subordinate to the national scale, with local people's actions dictated by political elites. Recent scholarship on anti-mining social movements in Mongolia [9,21] and Kyrgyzstan [22,23] has attempted to offset the supremacy of the state as the preeminent scale of analysis. This work highlights local communities' concerns about the environmental impacts of infrastructure projects, especially risks to water supply in this arid region. Infrastructural development in mountainous areas threatens the "primary source of fresh water for Central Asia's rivers and aquifers", while infrastructural demands for water in drier areas often endanger the health and environment-dependent livelihoods of isolated pastoral communities [24] (p. 979). In addition to posing a threat to water supplies, infrastructural development can exacerbate natural dust generation, which is a significant health risk to communities in Central Asian steppe drylands [5]. This health risk is aggravated by the potential for infrastructural accidents, such as dam failure or toxic spillages. These perceived threats can generate an 'environmentalism of the poor', causing local 'eco-mobilisations' to arise largely independently of other scales and actors [22].

In order to mediate between these two contrasting bodies of literature, there is a need to engage directly with the scalar and temporal dynamism of environmental protest in the Central Asian context. We attempt to understand how protests evolve in time and space, using a 'politics of scale' approach to provide a nuanced understanding of environmental mobilisation against Kumtor gold mine in Kyrgyzstan. This paper first examines the literature on the emergence and evolution of social movements in Central Asia. We endeavour to tease out the spatial limitations of current theories and introduce 'politics of scale' as a theoretical lens. Next, the origin and development of local opposition to Kumtor is explored, with an emphasis on the strategies the movement uses to set 'scales of meaning' and to scale-jump. The discussion then focuses on the tensions that arise when social movements attempt to position the local scale as the legitimate scale of meaning for environmental conflicts, while simultaneously forming coalitions with other actors to scale-jump local claims to national and global levels. The majority of the academic literature suggests that these local and scale-jumping strategies are complementary $[25,26]$, but this paper will argue that once social movements scale-jump to the national level they are more vulnerable to being co-opted by national actors to achieve alternate political ends. 


\section{Theories of Environmental Activism in Central Asia}

\subsection{Activism and the State}

Environmental movements against infrastructure developments are on the rise in Central Asia. There have been anti-mining movements in Mongolia [9,21], environmental justice movements in Kazakhstan [27] and Tajikistan [28], and a variety of environmental protests in Kyrgyzstan [22]. This rise of environmental activism has been interpreted in academia largely through the lens and at the scale of the state. Academic analysis of the role of the state in Central Asia has a distinguished pedigree. Following their delimitation by Soviet "nation-makers" in the 1920s [29,30], the Central Asian nations underwent a reluctant "catapult to independence" initiated by the collapse of the Soviet Union in 1991 [31,32]. As Central Asian political elites focused on constructing a "common-sense of belonging" in these artificial and multi-ethnic nations, academic scholarship on the region began to concentrate on their strategies of state and nation building [30,33-36].

This statist and elite-centric focus is pervasive in contemporary scholarship on Central Asian infrastructure. Fillippo Menga [4] demonstrates how large-scale construction projects intersect with elite-led nation-building in the case of Rogun dam in Tajikistan. The symbolic value of the hydraulic project enables the ruling elite to disseminate its own idea of the nation, progress and development. Similarly, the Turkmenistan-Afghanistan-Pakistan-India (TAPI) natural gas pipelines project is understood as a 'virtual pipeline'; its primary value exists in its generation of domestic discourses of progress [37] (p. 1). While the construction of border roads in Kyrgyzstan is conceptualised as an unruly process, often escaping the political visions that initiate them, the state is still the actor with primary political agency [17]. Infrastructure projects have considerable political potency in this region.

Academic accounts of the state and infrastructure in Central Asia have also highlighted the endemic problem of corruption. In Uzbekistan, the state is experienced as organised crime [38], while in Kyrgyzstan the state has become "an investment market" for members of the elite [39]. Much of this "criminalisation of the state" in Kyrgyzstan is centred around the Kumtor gold mine [40]. Allegedly, members of the Akaev regime were involved in the laundering of up to $\$ 15$ million using offshore vehicles [41]. In addition, a Kumtor executive estimated that half of the mining-funded Issyk Kul development fund disappears annually [42]. Political elites in Central Asia have maintained a "façade of compliance with international anticorruption standards" while consistently exploiting the state for private economic gain [43] (p. 26).

The dominance of the state-centric viewpoint has meant that analysis of resistance to infrastructure projects is often conducted through the lens and at the scale of the state. A primary way that statist literature understands social movements against infrastructure is as resource nationalism-the demand that the government increase its control over national resources [15]. Resource nationalism has been implicated in Kazakhstan [44], Mongolia [15] and Kyrgyzstan [7]. Its origin is often traced to the disparity between the wealth created by resources and levels of national poverty, contributing to a "growing sense amongst the citizens of mineral-rich countries that they have not received an appropriate share of the benefits" of resource extraction [45] (p. 10). This distrust of foreign investment is enhanced by the cultural changes that can come with it. In the case of Oyu Tolgoi mine in Mongolia, the decline of local herding coupled with the influx of Chinese mine workers trigger fears of Chinese colonization and threats to Mongolian national identity [13,15]. Resource nationalism does not emerge from the local level but is a strategy that "domestic elites employ in order to increase their control of natural resource" and gain political advantages [16,46] (p. 38).

State-centric accounts have also attributed the emergence of environmental social movements to subversive clientelism. Subversive clientelism is the theory that citizens may participate in environmental protests because elites ask them to [19]. This 'protest inauthenticity' has been implicated across Central Asia, from the state-managed 'Astroturf' protests in Russia [47] (p. 33) to the 'rent-a-mob' phenomenon in Kyrgyzstan [48]. In Kyrgyzstan, the failure of the state to meet society's basic economic needs has allowed elites to capture community support by providing material or symbolic 
investments $[19,20]$. When it is politically expedient for them, elites use mass support obtained through this subversive clientelism to mobilise against the state. In addition to developing their own support base, elites develop ties with other autonomous elites to expand their informal patronage networks [19]. The existence of a 'rent-a-mob' phenomenon is supported by a survey-based study in Kyrgyzstan, which found that $5.13 \%$ of respondents were offered some kind of compensation to participate in an environmental protest [22].

Theorisations of resource nationalism and subversive clientelism as triggers for environmental protests in Central Asia are heavily contested in the literature. These theories are considered to be reductionist, as they rely on material incentives, rational choice and cultural norms to interpret the behaviour of non-elites [40]. These assumptions constrain the political agency of ordinary citizens, providing a "spectator's view of action where non-elites are viewed in instrumental and passive terms" [49] (p. 15). Furthermore, this framing marginalised the real socio-environmental threats posed to locals by infrastructure projects. It is essential to analyse environmental protests from the viewpoint of the ordinary citizen, not just the elites [22].

In Central Asia, infrastructure development poses real environmental, material and cultural threats to local populations. These communities are often highly reliant on the environment for their livelihoods and wellbeing, and thus have a heightened understanding of what they stand to lose by not managing it carefully $[50,51]$. Threats to the environment, whether they materialise or not, can create 'relative deprivation' for local communities, generating local and specific grievances, which provide a general spur to activism [52,53]. Despite lacking meaningful capital, poor groups can undertake resistance ranging from overt, confrontational behaviour to subtle, everyday forms $[40,54,55]$. This 'environmentalism of the poor' is closely linked to the 'environmental justice' movement. Environment justice can be sub-divided into recognition, distributional and procedural components. Recognition refers to the acknowledgement of collective social identities and their specific needs, concerns and livelihoods [56]. Distributional environmental justice demands the equitable distribution within society of environmental benefits and burdens [57]. Procedural environmental justice calls for the just political and social functioning of society and its institutions, with an emphasis on participation in decision-making [57]. Several environmental mobilisations in Central Asia have been interpreted through an environmental justice lens $[9,21]$.

Political opportunity structures can also determine if, when and where a community protests $[58,59]$. Following the collective interest model, potential protestors evaluate their political environment and calculate the likelihood of success of their collective action [60]. If a protestor believes the action they take will likely result in the outcome they desire, they may be willing to risk the costs of acting [22]. Transient political opportunities may combine with long-standing environmental grievances to enhance the "eco-mobilizeability" of an individual at a specific time [22].

Political opportunity structures do not just influence the actions of the poor, they may also influence the actions of elites. When locally originating social movements achieve a certain level of popular support and political saliency, a political opportunity arises for elites to exploit. However, there has been limited analysis of how "community concerns about the environment may drive elite involvement and co-optation" [22] (p. 340). This is possibly because of a focus in the literature on how environmental movements emerge and the spectacular one-off protest events they engender. There is a need for a more prolonged assessment of environmental movements to understand how communities' grievances and elites' political aspirations intersect throughout the evolution of the movement. Similarly, there has been a lack of interaction with scale in the literature on environmental movements in Central Asia. The theories of eco-mobilisation and elite co-optation conceptualise environmental protests as static scalar entities predominantly operating on either the local or national scale. There is a dearth of analysis on how actors socially construct the scale of environmental movements to suit their own political interests. 


\subsection{Politics of Scale}

'Politics of scale' is a theory that allows for a more nuanced understanding of the dynamic scalar relations of environmental conflicts. This theory suggests that continuous social processes of socio-political and economic struggle occur between actors aiming to strengthen power and control of a certain scale while disempowering other scales [61,62]. Thus, scales are both socially constructed and politically contested, and are constantly in the process of being reorganized [63,64]. Actors engage strategically with scale to construct, hierarchize and reorganise territorial units in relation to each other $[63,65]$.

As a global business based on place specific mineral deposits, mining has a rich politics of scale. Mining is often described as a 'glocal' phenomenon: international networks of production and consumption are realised in local communities and environments $[66,67]$. The concept of 'glocalisation' was coined to nuance the homogenising power of globalisation by showing that the effects of globalising forces are contingent upon place-based characteristics $[62,66]$. With regards to resource extraction, 'glocalisation' is now used to describe the scale-creation and scale-adjustment ability of both extractive industries and movements resisting extraction [68].

Both 'politics of scale' and 'glocalisation' are useful concepts to understand how governments and corporations use specific geographical scales to define mining projects. Mining projects are largely negotiated at a bilateral level between governments and corporations, converting these extractive places into national spaces of development generation $[69,70]$. This creates a gap between the 'scales of meaning' at which a mining project is experienced or perceived, and the 'scales of regulation' at which the project is commercially approved and politically defined [71,72]. Anti-mining movements challenge the existing hegemonic power structures that define the environmental conflict by restructuring the scales of meaning and regulation [63]. This is achieved by mounting a defence of local place, while simultaneously strategically rescaling the movement in a 'glocal' fashion, often through allegiances with national and supra-national networks $[25,26]$.

Anti-mining movements jump scales from local to national to global in attempts to target concerns on certain geographical scales in order to challenge national decisions [26,64]. Scale-jumping can be achieved by creating broader networks of social actors from different geographical locations, expanding the geographical scale at which the anti-mining discourse operates [73]. These actors support local movements by providing experience, information, enhancing media attention and enabling a broader 'repertoire of contention' to include legal challenges $[69,74]$. A recent study found that when an environmental movement was connected to more civil society organisations, and especially when it was connected to more nationally or transnationally central civil society organisations, its outcome was more likely to be perceived as a success [75].

Including a wider range of actors and organisations in this broad network can result in initial discourses of local environmental justice being joined by broader discourses such as climate change, anti-neoliberal ideals and resource nationalism [76-78]. For instance, in the Pascua Lama conflict in Chile, local resistance movements referenced wider global claims such as climate change, glacier protection, democracy and participation [78]. In some cases, this can result in a loss of autonomy for local organisations, a need to alter strategies, ideological conflicts and identity loss [79]. Local movements need to be careful not to lose the grassroots while establishing links with supralocal organisations [75]. If there are inequities in coalitions, contradictory opinions on the appropriate values and arguments to use may mean that local environmental justice claims lose out to discourses introduced by more powerful supralocal organisations [80]. In Kyrgyzstan, where there are only 600-700 active national non-governmental organisations (NGOs) and few international organisations, local resistance movements may have to be less scrupulous about the social actors that they form advocacy networks with, increasing the likelihood of this discourse displacement [81]. 


\section{The Case of Kumtor}

\subsection{Introducing Kumtor}

The Kumtor gold deposit is the largest in Central Asia, and has been central to Kyrgyzstan's domestic economy since production started in 1997. In 2014, it accounted for 23.1\% of Kyrgyzstan's industrial output and 7.4\% of its GDP [7]. The economic importance of Kumtor to Kyrgyzstan has meant that the mine has been closely linked to national politics. The agreement between Cameco and the government in 1992 gave the Kyrgyz government about 60\% of shares in the Kumtor Operating Company (KOC) [82]. However, the Kyrgyz government periodically sold shares to Cameco to fund President Akaev's election campaigns [83]. By 2004 the Kyrgyz government only had 15.6\% of shares in Kumtor, while Cameco largely sold out to Centerra, another Canadian firm [83]. In 2009, Centerra and President Bakiev negotiated a New Terms Agreement that granted Kyrgyzstan a 33\% share of Centerra [84]. This agreement was still in place at the time of writing.

The local environmental movement originated to claim compensation for a major industrial accident. In May 1998, a truck travelling to the mine lost 1.7 tonnes of sodium cyanide, which dissolved into the Barskoon River (see Figure 1) [84]. Despite villagers not being informed of the spill for five hours, an international commission concluded that 'no carcinogenic, mutagenic, teratogenic, reproductive or neurotoxological effects to people are expected' [85] (p. iii). However, local residents and NGOs claimed that more than 2500 people were affected by poisoning, 800 went to hospital and four died as a result of the spill [86]. The Kumtor Operating Company (KOC) provided \$25 per adult as compensation for the accident, but local residents argued that this was insufficient compensation for the long-term health impacts and agricultural losses [86,87].

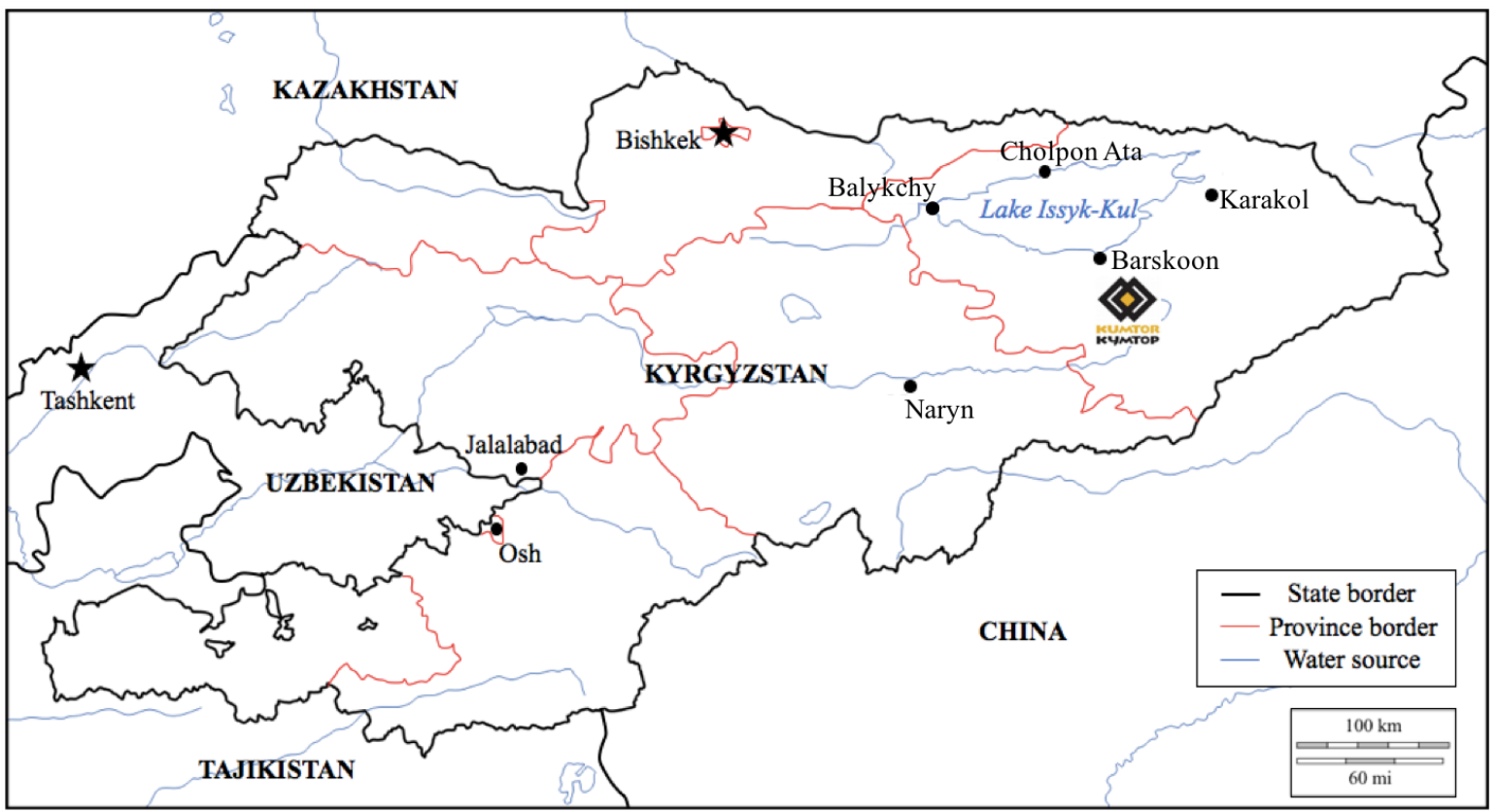

Figure 1. Map of Kyrgyzstan with Kumtor mine.

Local resident Erkingul Imankojoeva set up an NGO called Karek in 1998 to pursue locals' claims for compensation [88]. In addition to the preeminent demand for compensation, Karek also called for enhanced local economic benefits, ecological monitoring and improved safety measures [23]. Karek's 'repertoire of contention' was mostly limited to using protests and road blockades to pressurise Centerra and the government [23,59]. Local residents blockaded the road from Bishkek to the mine on at least five separate occasions between 1998 and 2006. In the July 2006 protest, more than 3000 locals blocked the main road leading to the mine in round-the-clock shifts [88]. In addition, Karek generated public 
awareness through conducting press meetings, accident victim photo exhibits and public showings of Zolotaya Avariya (Golden Accident), a film about the accident [23]. After advocating for compensation for eight years, in 2006, \$3.7 million was distributed to five villages in the area, mostly for harvest damages [23].

The initial claims articulated by local anti-Kumtor activists closely fit the thesis of the environmentalism of the poor. Karek framed the Kumtor issue using local place-based claims, articulating a discourse of environmental justice and human health. The considerable impacts of the Barskoon spill provided a clear grievance that local communities could rally around, and the movement was clearly contained to those impacted by the spill. The use of protests and roadblocks in the villages within Issyk-Kul province cemented this local scale as the legitimate 'scale of meaning' that should be taken into account in the decision-making around Kumtor. Indeed, subsequently, it has been shown that Kumtor may also be polluting the river Naryn that runs through several villages in the Naryn province [89]. However, this region has not received any compensation due to Karek's success in positioning the villages in Issyk-Kul province as the location of Kumtor's impacts.

Anti-Kumtor activists pursued several strategies to scale-jump their concerns to a national and global level. Karek created links with Bishkek-based NGOs such as Tree of Life through an 'eco-safety network' [23]. These national NGOs articulated a unified discourse that situated the local scale as the dominant scale of the anti-Kumtor lobby, which added emphasis to Karek's public awareness campaigns. This successfully raised the local, place-based compensation claims of Karek to the national level. Additionally, the local anti-Kumtor lobby allied with a small number of global organisations to scale-jump the issue to the global level. Dutch NGO Milieukontakt and the Organisation for Security and Cooperation in Europe organised workshops to train local NGOs, while the Urgent Action Fund for Women's Human Rights conducted an online campaign to generate financial support for Karek [23].

Supra-national networks have been widely acknowledged as crucial to the scale-jumping ability of local social movements [73-75]. However, in this example of anti-Kumtor activism, the roadblocks and protests were a successful scale-jumping strategy in and of themselves. Infrastructural sabotage and public demonstrations often halted production, reducing Centerra's profits, which adversely affected company share price and government tax revenue. In the five days after the initiation of the July 2005 protests Centerra's share price fell by $8 \%$, while in the five days after the initiation of the July 2006 protests, it fell by $28 \%$ (Table 1). Despite scale-jumping, the anti-Kumtor movement to the national and global level, the symbolic locus of the protests was clearly at the local point of disruption. Social movement theory has previously suggested that forming trans-national allegiances was critical to articulating a 'glocal' environmental conflict [26]. Local scale jumping strategies of this kind may negate the need for social movements to build trans-national allegiances in order to 'glocalise'. In fact, in the absence of these allegiances, environmental movements may be better positioned to retain the 'local' element of 'glocalisation'. This successful scale-jumping usage of protests, road blocks and NGO networks provided a template for other anti-Kumtor activists to follow [23].

Table 1. Response of Centerra Gold share price to Kumtor protests over a five-day period following protest onset (2005-2006).

\begin{tabular}{cc}
\hline Date & Percentage Change \\
\hline 18 July 2005 & -8.03 \\
3 August 2005 & 0.98 \\
1 November 2005 & -1.26 \\
17 May 2006 & -4.60 \\
13 July 2006 & -28.36 \\
\hline
\end{tabular}

\subsection{Diversifying Discourses}

Since the success of the movement to claim compensation for the Barskoon spill, the demands of the anti-Kumtor movement have diversified. Demands have shifted from demanding distributional 
environmental justice to demanding procedural environmental justice. These procedural justice demands have taken a variety of forms. A key argument of local NGOs is that Issyk-Kul province bears the environmental costs of Kumtor, but due to procedural and institutional inequity receives an incommensurate lack of economic benefits [23]. Between 1994 and 2012, KOC paid $\$ 2.15$ billion in tax and contributed $1 \%$ of its gross revenue to the Issyk-Kul Region Development Fund [84]. However, only a fraction of this money benefited local communities for two reasons. First, local governments receive 'shared revenue', taxes collected by the state and distributed equally to local administrations [90]. New legislation in 2011 meant that $2 \%$ of this total tax accrued directly to the local government of the mine, but Karek argues that this investment is inadequate compensation for the environmental issues associated with Kumtor [83]. Second, corruption prevents locals from benefitting from this investment. Karek has aligned with national anti-corruption NGOs Citizens Against Corruption and Taza Tabiyat to draw attention to how Kumtor has been used as 'an investment market' by political elites [39,91].

In addition to seeking procedural environmental justice in the form of equitable benefit-sharing, NGOs are leading the movement towards a more equal decision-making process. Currently, the Extractive Industries Transparency Initiative (EITI) in Kyrgyzstan is a top-down process, with all actions, decision-making and implementation centralised in Bishkek, "excluding regions altogether" [92] (p. 469). EITI meetings are conducted in Bishkek with no travel reimbursement for attendees, and reports are rarely translated into Kyrgyz [92]. 'Tree of Life' has been working to publicise and improve access to the EITI process in Kyrgyzstan [92].

Karek has aligned with national NGOs to criticise the Government and KOC on environmental grounds. The 'Tree of Life' argued that assigning part of the neighbouring Sarychat-Eertash nature reserve to a concession area of Kumtor contravened Kyrgyz regulations on environmental protection [22,90]. This NGO also organised protests in Bishkek in 2017 opposing glacier destruction by Kumtor [93]. The local anti-Kumtor campaign has also allied with national human rights NGOs Kylym Shamy (Torch of the Century) and Human Rights Bureau to publicise the issue of anti-Kumtor activists being beaten and tortured $[23,94]$. These NGOs have videotaped conversations with KOC officials and shared photographs of activists beaten in police custody [95].

After the success of the movement for compensation, the localised anti-Kumtor movement jumped scale to the national level by deepening allegiances with a diverse range of national NGOs. This mirrors Robbins' [96] observation that environmental movements emerge in response to material threats, but subsequently build 'bridges' to broader struggles. This bridge building has resulted in initial discourses of local environmental justice being joined by broader discourses introduced from the national and global sphere, constructing "completely entwined arguments and values in a glocal process" [78] (p. 225). For example, Tree of Life introduced post-materialist conservationist values to argue for the protection of nature from Kumtor, but directly related this back to the local level by arguing that glacier destruction presents a threat to local water supplies [93].

\subsection{Overpowering Discourses}

The initial success of the original localised anti-Kumtor movement, coupled with the formation of the supralocal allegiance network, succeeded in raising the political prominence of Kumtor at the national level. Ordinary people began engaging with Kumtor as an informal symbol of resistance to the state vision of development. The political prominence and symbolic nature of Kumtor made it an attractive political prospect for certain political elites to associate themselves with. Following the revolution of 2010, the Ata-Jurt political party has capitalised on this political opportunity, promoting nationalisation of Kumtor to undermine the Government.

Political elites do not passively join environmental movements in Kyrgyzstan, they actively shift the discourses and scale of the movement to suit their own ends. In 2012, Ata-Jurt MP Sadyr Japarov formed a parliamentary commission to assess the mine's environmental impact [42]. The 300-page report was published in June 2012, and alleged that the open cast mine had negatively impacted on the 
nearby glacier and rare plant species, along with poisoning streams feeding into the Barskoon river [97]. In an interview, Japarov stated that "all works at Kumtor have been implemented with violations of ecological regulations" [98]. Many of the environmental issues highlighted by this commission were similar to those broadcast by the local socio-environmental movement. However, these issues were framed as a failure of the government to protect the national legacy of Kyrgyzstan's environment, as opposed to the environmental justice framing of the local movement, which emphasised the impacts on local livelihoods. Although Japarov's call to nationalise Kumtor was defeated in parliament, he was successful in bringing the environmental issues of Kumtor back to the forefront of Kyrgyz politics.

On 3 October 2012, 1000 people attended a nationalisation rally in Bishkek organised by Ata-Jurt [84]. Party leader Kamchibek Tashiyev gave an inflammatory speech in which he proclaimed that "nobody but the nation should run the Kumtor (mine)" [98]. Following the speech, Tashiyev unsuccessfully led protestors in attempting to break into the parliament building, which resulted in his arrest [99]. Afterwards, Tashiyev claimed that Ata-Jurt "wanted the Kumtor problem to be raised to the state level" as "Kumtor is something that affects all Kyrgyz" [100,101]. This rally constituted another shifting of the 'scale of meaning' of the Kumtor problem to the national level. By arguing that Kumtor should be run by "the nation" as it "affects all Kyrgyz" and symbolically locating the protest outside the parliament building, this rally shifted the 'scale of meaning' of the anti-Kumtor movement to the national level, while simultaneously divorcing it from the local anti-Kumtor campaign [98,101].

These demands for the nationalisation of the mine spread to local anti-Kumtor campaigns (see Table 2). Although some NGOs spoke out against the Ata Jurt led calls for nationalisation, describing them as an attempt to "score some political points", the majority of locals supported this discursive shift [101]. From 28-31 May 2013, around 3000 protestors blocked the road to the mine demanding that environmental standards be upheld and that Kumtor be nationalised [102,103]. On 30th May, they seized an electricity station, disrupting power to the mine [103]. Clashes between protestors and police resulted in 92 people being arrested and 55 people being wounded [83]. Two months later a video appeared on state television showing two informal leaders of the May Barskoon protest demanding $\$ 3$ million from a KOC director in exchange for a guarantee not to orchestrate protests [96]. In the video, both men claim to have the support of Ata-Jurt politicians Kamchybek Tashiyev and Sadyr Japarov, leading to claims in the Kyrgyz media that the Kumtor protests are another 'rent-a-mob' incident $[42,104,105]$. While the demands and the timing of the May protest certainly suited Ata-Jurt politically, the connection between Ata-Jurt and the local environmental movement does not fit with Radnitz' [19] theory of subversive clientelism. In subversive clientelism, elites utilise local support bases, but Ata-Jurt politicians Kamchybek Tashiyev and Sadyr Japarov originate from Southern Kyrgyzstan, and thus are geographically and politically removed from the Issyk-Kul oblast. Furthermore, local people have mobilised against Kumtor on environmental grounds for over a decade, well before nationalisation of the mine was politicised by Ata-Jurt. Additionally, subversive clientelism describes the mechanism by which elites initiate protests, not how they co-opt pre-existing movements.

We argue that the calls for resource nationalism in local Kumtor protests are indicative of a more passive elite co-optation of popular protests. The strong public profiles of Ata-Jurt politicians allowed them to monopolise media attention, facilitating an elite domination of anti-Kumtor discourse production and scalar framing. This discursive dominance is augmented by the potential of resource nationalism as a framing strategy. Resource nationalism is potent in Kyrgyzstan due to the extensive nation-building strategies implemented by the state, while depicting the sovereignty of Kyrgyzstan as threatened was particularly compelling at the time due to the perception that the sovereignty of the nation was vulnerable following the riots of $2010[84,106]$. Finally, the 'infrastructural hope' of resource nationalism is tempting in Kyrgyzstan where $32.1 \%$ of the population is below the poverty line $[17,107]$.

The popularity of the resource nationalism discourse espoused by Ata-Jurt created a political opportunity for local protesters to enhance the political saliency of the local anti-Kumtor movement 
and scale-jump to the national scale. In this model of elite co-optation, local protestors are not passive victims, stripped of agency. They are active collaborators opportunistically pursuing a political opportunity.

Utilising the discourse of resource nationalism has enrolled national support for the anti-Kumtor movement, but has consolidated the Kumtor problem as a national rather than a local issue. This has undermined local claims for procedural and distributional environmental justice, preventing a decentralisation of the power, decisions and benefits of Kumtor. By articulating Kumtor as a problem of national relevance, and advocating for nationalisation as a solution, anti-Kumtor activists have empowered the national scale as the 'scale of meaning' of this environmental conflict. As a result, attempted 'solutions' to the dispute have been national in scale. In January 2014, the government approved a deal to swap its $32.7 \%$ stake in Centerra for a $50 \%$ stake in KOC, though this deal was subsequently rejected by parliament [108]. In 2017, the government reached another deal with Centerra, which involved KOC making one-time payments of US \$7 million to a new, government-administered Cancer Care Support Fund and US \$50 million to a new, government-administered Nature Development Fund [109]. These solutions pander to the calls for resource nationalism and environmental protection advocated by national actors, but fail to resolve local calls for environmental justice in the face of threats to their livelihoods.

Table 2. Location and demands of reported Kumtor protests.

\begin{tabular}{|c|c|c|c|}
\hline Date & Location & Demands & Citation \\
\hline 10 July 1998 & Local & Compensation & Wooden, 2017 [23] \\
\hline 18 July 2005 & Local & Compensation & $\begin{array}{c}\text { Institute for War \& Peace } \\
\text { Reporting (IWPR), } 2006[86]\end{array}$ \\
\hline 3 August 2005 & Local & Compensation & $\begin{array}{l}\text { Radio Free Europe/Radio } \\
\text { Liberty (RFE/RL), } 2005 \text { [87] }\end{array}$ \\
\hline 1 November 2005 & Local & Compensation & New York Times, 2005 [110] \\
\hline 17 May 2006 & Karakol & Compensation & Wooden, 2013 [22] \\
\hline 13 July 2006 & Local & Compensation & Wooden, 2013 [22] \\
\hline 18 April 2007 & Bishkek & Local environment and economy & Wooden, 2013 [22] \\
\hline 19 April 2007 & Local & Local environment and economy & Wooden, 2013 [22] \\
\hline 7 May 2007 & Local & Compensation & RFE/RL, 2007 [111] \\
\hline 25 January 2011 & Local & Local environment and economy & Transitions (TOL), 2011 [42] \\
\hline 16 February 2011 & Bishkek & Improve regional infrastructure, & Wooden, 2013 [22] \\
\hline 4 June 2012 & Local & Local environment and economy & Reuters, 2012 [112] \\
\hline 3 October 2012 & Bishkek & Nationalisation & Gullette, 2014 [84] \\
\hline 4 October 2012 & Jalalabad & Nationalisation & Gullette, 2014 [84] \\
\hline 5 October 2012 & Jalalabad & Nationalisation & RFE/RL, 2012 [99] \\
\hline 8 October 2012 & Jalalabad & Nationalisation & RFE/RL, 2012 [113] \\
\hline 13 March 2013 & Bishkek & Nationalisation & RFE/RL, 2013 [114] \\
\hline 24 April 2013 & Bishkek & Nationalisation & RFE/RL, 2013 [100] \\
\hline 28 May 2013 & Local & Environment, Nationalisation & RFE/RL, 2013 [103] \\
\hline 3 June 2013 & Jalalabad & Nationalisation & IWPR, 2013 [115] \\
\hline 27 July 2013 & Local & Cancel contract with Centerra & RFE/RL, 2013 [116] \\
\hline 28 August 2013 & Local & Nationalisation & Gullette, 2014 [84] \\
\hline 7 October 2013 & Karakol & Nationalisation & Gullette, 2014 [84] \\
\hline 8 October 2013 & Local & Nationalisation & RFE/RL, 2013 [116] \\
\hline 11 October 2013 & Local & Nationalisation & K-News, 2013 [117] \\
\hline 25 March 2014 & Local & Distribute benefits locally & AKIpress, 2014 [118] \\
\hline 29 April 2014 & Local & Distribute benefits locally & Gullette, 2014 [84] \\
\hline 8 November 2017 & Bishkek & Glacier law change & IWPR, 2017 [48] \\
\hline
\end{tabular}

\section{Discussion}

Local social movements are often trapped in a scalar bind; they must choose between emphasising local demands (and risk remaining irrelevant on a national level) or appealing to national or global sympathies (and risk marginalising local concerns). The local environmental movement against Kumtor was initially able to escape this scalar bind. The lack of international NGOs operating in Kyrgyzstan meant that the local anti-Kumtor movement pursued a largely autonomous scale-jumping 
strategy. Protests and roadblocks in local villages produced the local scale as the legitimate 'scale of meaning', while disrupting the transport of goods to and from the mine, scale-jumping the issue to national and global prominence. Local NGOs also allied with national NGOs in an effort to publicise the plight of local communities. These allegiances were deepened following the success of the initial movement for compensation, resulting in the introduction of broader discourses to the anti-Kumtor movement such as post-materialist environmentalism, transparency and corruption, and human rights (Table 3). This trend of diversifying discourses as an environmental movement matures has been documented in Latin America, where environmental movements adjusted their terminology to reflect contemporary struggles, resulting in a hybridisation of local social justice and broader ecological concerns [119].

Table 3. Broad trajectory of the anti-Kumtor movement.

\begin{tabular}{cccc}
\hline Timing & Main Demands & Key Actors & Scale of Meaning \\
\hline 1997-2006 & Compensation & Local NGOs (Karek) & Local \\
\hline \multirow{2}{*}{$2006-2012$} & $\begin{array}{c}\text { Economic distribution } \\
\text { Human rights } \\
\text { Environmental } \\
\text { Procedural justice }\end{array}$ & $\begin{array}{c}\text { Local NGOs (Karek) } \\
\text { National NGOs (Tree of Life, Taza } \\
\text { Tabiyat, Human Rights Bureau) }\end{array}$ & Local/National \\
\hline 2012-2014 & Nationalisation & $\begin{array}{c}\text { National political party (Ata Jurt) } \\
\text { Local activists }\end{array}$ & National \\
\hline
\end{tabular}

When supralocal actors introduce discourses to local environmental movements, the new discourses can hybridise with pre-existing environmental justice claims, or they may overpower local concerns. As Ata-Jurt's calls for the nationalisation of Kumtor grew in political prominence, there was a palpable shift towards nationalisation in the demands of the local environmental movement. This is in agreement with Central Asian literature, suggesting that resource nationalism does not originate at the local level, but is a political strategy used by national elites $[16,46]$. While adopting resource nationalism increased the national resonance of the local anti-Kumtor movement, it also positioned Kumtor as a national issue, undermining local claims for environmental justice. This contradicts claims in the literature that local environmentalism of the poor and glocal rescaling strategies are compatible strategies to escape the scalar bind $[25,26]$. Jumping scales may not always enable anti-mining movements to challenge hegemonic scalar power relations, and occasionally can lead to their reinforcement.

Forming advocacy allegiances with contentious political groups can transform perceptions of the causes and demands of environmental protests. Ata-Jurt's involvement was widely perceived as an attempt to "score some political points" [101] or a "shakedown scheme" [42]. In Mongolia, when the controversial Fire Nation, an ethno-nationalist group, allied with environmental NGOs, the organisation was described as having "rebranded itself as an environmentalist organisation" [120]. In these cases, forming an advocacy network with controversial organisations led to the real environmental issues being marginalised.

The discursive shift of the local environmental movement towards resource nationalism contradicts existing theorisations of subversive clientelism. The local movement against Kumtor originated as an autonomous ecomobilisation in response to a specific grievance, and showcased an environmentalism of the poor. Existing theories of structured elite co-optation describe how elites initiate protests, rather than how they co-opt pre-existing movements [19]. These reductionist theories of subversive clientelism struggle to elucidate the discursive shift of the local anti-Kumtor movement. Instead, this paper argues for a more nuanced co-optation, suggesting that the discursive shift of the local movement occurred due to the ability of Ata-Jurt to monopolise media attention and dominate production of national discourses regarding Kumtor. While some local activists resisted this discursive co-optation, the majority acquiesced to the resource nationalism framing of the Kumtor issue. 
The decision of Ata-Jurt to discursively co-opt the Kumtor issue to suit its own political ends, and the acquiescence of local activists to the resource nationalism discourse can be understood through political opportunity structure theory $[58,59]$. There was a political opportunity for Ata Jurt to co-opt the Kumtor issue in 2012; as Kumtor was nationally prominent, protests organised by the local movement had reduced following the awarding of compensation in 2006 (Table 2), playing on concerns for national sovereignty powerfully following the recent 2010 riots [84], and Ata-Jurt needed to distract from criminal charges against several of its members [101]. Aligning with Ata-Jurt was a political opportunity for the local movement due to the extensive media presence of Ata Jurt politicians, which drew attention to Kumtor and the paucity of other international and national actors available to form a network to scale-jump the issue to supralocal levels. In this model of elite co-optation, local protestors are not passive victims, but active collaborators pursuing a political opportunity.

Transient elite involvement in locally originating environmental issues is not limited to Kyrgyzstan; it is widely prevalent across Central Asia. When the Mongolian Ongi River Movement became politically prominent, electoral candidates joined protest marches and advertised their support [21]. However, the River Movement adhered to its initial framing of mining as a local environmental issue, and refrained from engaging with "politically ambitious and predominantly urban-based" movements that emphasised the political and economic drawbacks of mining [21] (p. 94). This contrasts with the discursive Faustian bargain made by the local Kumtor environmental movement with Ata-Jurt. From this contrast, we suggest that the ability of a social movement to resist elite co-optation may depend on the strength and clarity of the movement's identity. Movements may be more vulnerable to elite co-optation when they become salient on the national level, but also when they start to embody a wider range of demands that locals do not relate to.

\section{Conclusions}

Kumtor is often framed as either a question of "the vision of the state and the role of strategic resources in the present and future of the country" [7] (p. 9), or local "social, economic and environmental issues combined" [3]. Tracing the trajectory of anti-Kumtor protests in Kyrgyzstan shows that environmental activists often engage with both of these framings, relating to theories that social movements must simultaneously legitimise the local level as the 'scale of meaning' while scale-jumping local claims to supralocal relevance through advocacy networks. However, due to the dearth of civil society actors in Kyrgyzstan and lack of international NGOs operating in the region, the onus is often on social movements to scale-jump independently of advocacy networks. The Kumtor movement achieved this by disrupting access to the mine, affecting production and generating fluctuations in the Canadian company's share price. This demonstrates that social movements are not dependent on extensive networks to scale-jump, but have the ability to do so autonomously.

When situated environmental claims become nationally prominent, they become attractive targets for elite co-optation. In the case of Kumtor, this elite co-optation is unlikely to have been through structured channels and material incentives proposed by subversive clientelism [19]. We theorise that a more passive elite involvement in anti-Kumtor protests occurred through discourse monopolisation and opportunistic local alignment. This discursive co-optation by elites can restrict the ability of local movements to scale-jump to the national level in Post-Soviet Kyrgyzstan. In order to scale-jump to the national level and escape the scalar bind, movements may need to undertake autonomous scale-jumping, or form extensive horizontal networks with other national and international local groups.

This paper identifies three critical research areas for further study. First, there has been limited analysis of the dynamic nature of environmental movements in Central Asia. Shifting focus from understanding the demands of emerging environmental movements to tracing the emergent demands of environmental movements would shed light on how a stable civil society could function in this region. Second, an improved understanding of more passive ways that elites interact with and influence environmental protests would nuance the current highly structured theorisations. There is 
need for further study to assess strategies that local activists use to resist discursive co-optation. Third, accounts of environmental threats in Central Asia need to engage with how actors socially construct scale. These broad research themes would facilitate a more reflexive understanding of environmental movements in Central Asia.

Acknowledgments: Ariell Ahearn and Troy Sternberg provided advice and insightful comments on earlier drafts of this manuscript. Three anonymous reviewers made discerning recommendations that improved the manuscript.

Conflicts of Interest: The author declares no conflict of interest.

\section{References}

1. Mackinder, H.J. The geographical pivot of history. R. Geogr. Soc. 1904, 170, 298-321. [CrossRef]

2. Resource Investor China Secures Gas from Turkmenistan: Who's the Real Winner? 2009. Available online: http:/ / www.resourceinvestor.com/News/2009/12/Pages/China-secures-gas-from-TurkmenistanWhos-the-real-winner.aspx (accessed on 16 February 2018).

3. The Guardian. Tensions Flare over Environmental Threat of Canadian Gold Mine in Kyrgyzstan. Available online: https:/ / www.theguardian.com/global-development/2016/jan/05/environmental-threat-canadiangold-mine-kyrgyzstan (accessed on 5 March 2018).

4. Menga, F. Building a Nation through a Dam: The Case of Rogun in Tajikistan. Natl. Pap. 2015, 43, 479-494. [CrossRef]

5. Sternberg, T.; Edwards, M. Desert Dust and Health: A Central Asian Review and Steppe Case Study. Int. J. Environ. Res. Public Health 2017, 14, 1342. [CrossRef] [PubMed]

6. Abdolvand, B.; Mez, L.; Winter, K.; Mirsaeedi-Gloßner, S.; Schütt, B.; Rost, K.; Bar, J. The dimension of water in Central Asia: Security concerns and the long road of capacity building. Environ. Earth Sci. 2015, 73, 897-912. [CrossRef]

7. Fumagalli, M. The Kumtor Gold Mine and the Rise of Resource Nationalism in Kyrgyzstan. Central Asian Economic Paper, No. 16. 2015. Available online: https://app.box.com/s/ qeluit6p5qmg8sohl21qmx13gpt87pu5 (accessed on 31 March 2018).

8. Sternberg, T.; Ahearn, A.; McConnell, F. Central Asian 'characteristics' on China's new Silk Road: The role of landscape and the politics of infrastructure. Land 2017, 6, 55. [CrossRef]

9. Byambajav, D. Mobilizing against dispossession: Gold mining and a local resistance movement in Mongolia. J. Cent. North. Humanit. 2012, 5, 13-32.

10. Dani, A.H. History of Civilizations of Central Asia: Towards the Contemporary Period: From the Mid-Nineteenth to the End of the Twentieth Century, 1st ed.; UNESCO: Paris, France, 2005.

11. Hughes, G. Mining, Development and Environment in Central Asia: Toolkit Companion with Case Studies. 2012. Available online: http://www.zoinet.org/web/sites/default/files/publications/companion_ENG. pdf (accessed on 16 February 2018).

12. The Economist Gold in the Hills—Mining in Kyrgyzstan, 2013. Available online: https:/ / www.economist. $\mathrm{com} /$ news/asia/21573615-attitudes-towards-foreign-investors-hold-troubled-country-back-gold-hills (accessed on 16 February 2018).

13. Jackson, S.L. Imagining the mineral nation: Contested nation-building in Mongolia. Natl. Pap. 2015, 43, 437-456. [CrossRef]

14. Kassenova, N. China's Silk Road and Kazakhstan's Bright Path: Linking Dreams of Prosperity. Asian Policy 2017, 24, 110-116. [CrossRef]

15. Jackson, S.L.; Dear, D. Resource extraction and national anxieties: China's economic presence in Mongolia. Eurasian Geogr. Econ. 2016, 57, 343-373. [CrossRef]

16. Ganbold, M.; Ali, S.H. The peril and promise of resource nationalism: A case analysis of Mongolia's mining development. Resour. Policy 2017, 53, 1-11. [CrossRef]

17. Reeves, M. Infrastructural Hope: Anticipating 'Independent Roads' and Territorial Integrity in Southern Kyrgyzstan. Ethnos 2017, 82, 711-737. [CrossRef]

18. Doolot, A.; Heathershaw, J. State as resource, mediator and performer: Understanding the local and global politics of gold mining in Kyrgyzstan. Cent. Asian Surv. 2015, 34, 93-109. [CrossRef] 
19. Radnitz, S. Weapons of the Wealthy: Predatory Regimes and Elite-Led Protests in Central Asia, 1st ed.; Cornell University Press: New York, NY, USA, 2010.

20. McGlinchey, E. Central Asian Protest Movements: Social Forces or State Resources. In The Politics of Transition in Central Asia and the Caucasus: Enduring Legacies and Emerging Challenges, 1st ed.; Wooden, A.E., Stefes, C.H., Eds.; Routledge: New York, NY, USA, 2009; pp. 124-138.

21. Byambajav, D. The River Movements' Struggle in Mongolia. Soc. Mov. Stud. 2015, 14, 92-97. [CrossRef]

22. Wooden, A.E. Another way of saying enough: Environmental concern and popular mobilization in Kyrgyzstan. Post-Sov. Aff. 2013, 29, 314-353. [CrossRef]

23. Wooden, A.E. Images of Harm, Imagining Justice. In ExtrACTION: Impacts, Engagements, and Alternative Futures, 1st ed.; Jalbert, K., Willow, A., Casagrande, D., Paladino, S., Eds.; Routledge: New York, NY, USA, 2017; pp. 169-183.

24. Howard, K.W.; Howard, K.K. The new "Silk Road Economic Belt" as a threat to the sustainable management of Central Asia's transboundary water resources. Environ. Earth Sci. 2016, 75, 976-988. [CrossRef]

25. Escobar, A. Culture Sits in Places: Reflections on Globalism and Subaltern Strategies of Localization. Pol. Geogr. 2001, 20, 139-174. [CrossRef]

26. Urkidi, L. The Defence of Community in the Anti-Mining Movement of Guatemala. J. Agrar. Chang. 2011, 11, 556-580. [CrossRef]

27. Waters, K. The Fight for Community Justice against Big Oil in the Caspian Region: The Case of Berezovka, Kazakhstan. In Environmental Justice and Sustainability in the Former Soviet Union, 1st ed.; Agyeman, J., Ogneva-Himmelberger, Y., Eds.; MIT Press: Cambridge, MA, USA, 2009; pp. 153-189.

28. Strucker, D. Environmental Injustices, Unsustainable Livelihoods, and Conflict: Natural Capital Inaccessibility and Loss among Rural Households in Tajikistan. In Environmental Justice and Sustainability in the Former Soviet Union, 1st ed.; Agyeman, J., Ogneva-Himmelberger, Y., Eds.; MIT Press: Cambridge, MA, USA, 2009; pp. 237-275.

29. Kolstǿ, P. Political Construction Sites: Nation-Building in Russia and the Post-Soviet States, 1st ed.; Westview Press: Boulder, CO, USA, 2000.

30. Roy, O. The New Central Asia: The Creation of Nations, 1st ed.; I. B. Tauris: London, UK, 2000.

31. Suyarkulova, M. Reluctant Sovereigns? Central Asian States' Path to Independence. In Sovereignty after Empire Comparing the Middle East and Central Asia, 1st ed.; Cummings, S.N., Hinnesbusch, R., Eds.; Edinburgh University Press: Edinburgh, UK, 2011; pp. 127-157.

32. Olcott, M.B. Central Asia's catapult to independence. Foreign Aff. 1991, 71, 108-130. [CrossRef]

33. Isaacs, R.; Polese, A. Between "imagined" and "real" nation-building: Identities and nationhood in post-Soviet Central Asia. Natl. Pap. 2015, 43, 371-382. [CrossRef]

34. Akiner, S. The Struggle for Identity. In After Empire: The Emerging Geopolitics of Central Asia, 1st ed.; Snyder, J., Ed.; National Defense University Press: Washington, DC, USA, 2015; pp. 3-36.

35. Akbarzadeh, S. Nation-Building in Uzbekistan. Cent. Asian Surv. 1996, 15, 23-32. [CrossRef]

36. Akbarzadeh, S. National Identity and Political Legitimacy in Turkmenistan. Natl. Pap. 1999, 27, $271-290$. [CrossRef]

37. Anceschi, L. Turkmenistan and the virtual politics of Eurasian energy: The case of the TAPI pipeline project. Cent. Asian Surv. 2017, 36, 409-429. [CrossRef]

38. Rasanayagam, J. Informal Economy, Informal State: The Case of Uzbekistan. Int. J. Sociol. Soc. Policy 2011, 31, 681-696. [CrossRef]

39. Engvall, J. The State as Investment Market: An Analytical Framework for Interpreting Politics and Bureaucracy in Kyrgyzstan. Ph.D. Thesis, Uppsala University, Uppsala, Sweden, 2011.

40. Satybaldieva, E. Political Capital, Everyday Politics and Moral Obligations: Understanding the Political Strategies of Various Elites and the Poor in Kyrgyzstan. Eur.-Asia Stud. 2015, 67, 370-387. [CrossRef]

41. Asia Times Kumtor Report Raises Corruption Concerns, 2014. Available online: http://www.atimes.com/ atimes/Central_Asia/CEN-01-100914.html (accessed on 18 November 2017).

42. Transitions (TOL). In Kyrgyzstan, a Kumtor Shakedown or Setup? 2013. Available online: http:/ / www.tol.org/ client/article/23923-in-kyrgyzstan-a-kumtor-shakedown-or-setup.html (accessed on 18 November 2017).

43. Cooley, A.; Sharman, J.C. Blurring the line between licit and illicit: Transnational corruption networks in Central Asia and beyond. Cent. Asian Surv. 2015, 34, 11-28. [CrossRef] 
44. Cutler, R.M. Kazakhstan's 'Resource Nationalism': Its Sources and Motives. Central Asian Economic Paper, No. 2. 2012, pp. 1-6. Available online: https://app.box.com/s/zs1iu7rg5kw4zwycs24c (accessed on 31 March 2018).

45. Humphreys, D. Transatlantic Mining Corporations in the Age of Resource Nationalism, 1st ed.; Transatlantic Academy: Washington, DC, USA, 2012.

46. Domjan, P.; Stone, M. A comparative study of resource nationalism in Russia and Kazakhstan 2004-2008. Eur.-Asia Stud. 2010, 62, 35-62. [CrossRef]

47. Robertson, G.B. The Politics of Protest in Hybrid Regimes: Managing Dissent in Post-Communist Russia, 1st ed.; Cambridge University Press: Cambridge, UK, 2011.

48. Institute for War \& Peace Reporting (IWPR) Kyrgyzstan: Protests on Demand: Marginalised Groups Serve as Rent-a-Mob Demonstrators Whenever the Country is Convulsed by Unrest, 2010. Available online: http:/ / www.iwpr.net/report-news/kyrgyzstan-protests-demand (accessed on 3 December 2017).

49. Satybaldieva, E. A mob for hire? Unpacking older women's political activism in Kyrgyzstan. Cent. Asian Surv. 2018, 1, 1-18. [CrossRef]

50. Guha, R. Environmentalism: A Global History; Longman: New York, NY, USA, 2000.

51. Martínez-Alier, J. Mining Conflicts, Environmental Justice, and Valuation. J. Hazard. Mater. 2001, 86, $153-170$. [CrossRef]

52. Dalton, R.; Van Sickle, A.; Weldon, S. The individual-institutional nexus of protest behaviour. Br. J. Political Sci. 2010, 40, 51-73. [CrossRef]

53. Gurr, T.R. Why Men Rebel, Boulder; Paradigm Publishers: Boulder, CO, USA, 1970.

54. Kerkvliet, B.J. Everyday politics in peasant societies (and ours). J. Peasant Stud. 2009, 36, 227-243. [CrossRef]

55. Scott, J.C. Weapons of the Weak: Everyday Forms of Peasant Resistance; Yale University Press: New Haven, CT, USA, 1985.

56. Guha, R.; Martínez-Alier, J. Varieties of Environmentalism. Essays North and South; Earthscan: London, UK, 1997.

57. Schlosberg, D. Defining Environmental Justice: Theories, Movements, and Nature; Oxford University Press: Oxford, UK, 2009.

58. Buttel, F.H. New Directions in Environmental Sociology. Annu. Rev. Sociol. 1987, 13, 465-488. [CrossRef]

59. Tilly, C. Contention and Democracy in Europe, 1650-2000; Cambridge University Press: Cambridge, UK, 2004.

60. Lubell, M.; Vedlitz, A.; Zahran, S.; Alston, L.T. Collective Action, Environmental Activism, and Air Quality Policy. Political Res. Q. 2006, 59, 149-160. [CrossRef]

61. Smith, N. Geography, difference and the politics of scale. In Postmodernism and the Social Sciences, 1st ed.; Doherty, J., Graham, E., Malek, M., Eds.; Macmillan: London, UK, 1992; pp. 57-79.

62. Swyngedouw, E. Neither Global nor Local: Glocalization and the Politics of Scale. In Spaces of Globalization, 1st ed.; Cox, K., Ed.; Guilford Press: New York, NY, USA, 1997; pp. 137-166.

63. Brenner, N. The Limits to Scale? Methodological reflections on Scalar Structuration. Prog. Hum. Geogr. 2001, 25, 591-614. [CrossRef]

64. Vela-Almeida, D.; Kolinjivadi, V.; Kosoy, N. The building of mining discourses and the politics of scale in Ecuador. World Dev. 2018, 103, 188-198. [CrossRef]

65. Leitner, H.; Sheppard, E.; Sziarto, K.M. The spatialities of Contentious Politics. Trans. Inst. Br. Geogr. 2008, 33, 157-172. [CrossRef]

66. Robertson, R. Social Theory and Global Culture; Sage: London, UK, 1992.

67. Suopajärvi, L.; Ejdemo, T.; Klyuchnikova, E.; Korchak, E.; Nygaard, V.; Poelzer, G.A. Social impacts of the "glocal" mining business: Case studies from Northern Europe. Miner. Econ. 2017, 30, 31-39. [CrossRef]

68. Bebbington, A. NGOs and uneven development: Geographies of development intervention. Prog. Hum. Geogr. 2004, 28, 725-745. [CrossRef]

69. Triscritti, F. Mining, development and corporate-community conflicts in Peru. Community Dev. J. 2013, 48, 437-450. [CrossRef]

70. Barton, J.; Román, Á.; Fløysand, A. Resource extraction and local justice in Chile: conflicts over the commodification of spaces and the sustainable development of places. In New Political Spaces in Latin American Natural Resource Governance, 1st ed.; Haarstad, H., Ed.; Palgrave Macmillan: New York, NY, USA, 2012; pp. 107-128. 
71. Bebbington, A. Capitals and capabilities: A framework for analyzing peasant viability, rural livelihoods and poverty. World Dev. 1999, 27, 2021-2044. [CrossRef]

72. Kurtz, H.E. Scale frames and counter-scale frames: Constructing the problem of environmental injustice. Political Geogr. 2003, 22, 887-916. [CrossRef]

73. Urkidi, L.; Walter, M. Dimensions of environmental justice in anti-gold mining movements in Latin America. Geoforum 2011, 42, 683-695. [CrossRef]

74. Keck, M.; Sikkink, K. Activist beyond Borders. Advocacy Networks in International Politics; Cornell University Press: Ithaca, NY, USA, 1998.

75. Aydin, C.I.; Ozkaynak, B.; Rodríguez-Labajos, B.; Yenilmez, T. Network effects in environmental justice struggles: An investigation of conflicts between mining companies and civil society organizations from a network perspective. PLoS ONE 2017, 12, e0180494. [CrossRef] [PubMed]

76. Bebbington, A.; Bebbington, D.H.; Bury, J.; Lingan, J.; Muñoz, J.P.; Scurrah, M. Mining and social movements: Struggles over livelihood and rural territorial development in the Andes. World Dev. 2008, 36, 2888-2905. [CrossRef]

77. Gudynas, E. Buen Vivir: Today's tomorrow. Development 2011, 54, 441-447. [CrossRef]

78. Urkidi, L. A Glocal Environmental Movement against Gold Mining: Pascua-Lama in Chile. Ecol. Econ. 2010, 70, 219-227. [CrossRef]

79. Mix, T.L. Rally the people: Building local-environmental justice grassroots coalitions and enhancing social capital. Soc. Inq. 2011, 81, 174-194. [CrossRef]

80. Schlosberg, D. Networks and Mobile Arrangements: Organisational Innovation in the US Environmental Justice Movement. Environ. Politics 1999, 8, 122-148. [CrossRef]

81. Asian Development Bank. Civil Society Briefs: The Kyrgyz Republic. Available online: https://www.adb. org/sites/default/files/publication/29443/csb-kgz.pdf (accessed on 29 March 2018).

82. Eurasianet. Kyrgyzstan: Could Kumtor Shakedown Backfire on Bishkek? Available online: http://www. eurasianet.org/node/63603 (accessed on 17 November 2017).

83. Yuldashev, F.; Sahin, B. The political economy of mineral resource use: The case of Kyrgyzstan. Resour. Policy 2016, 49, 266-272. [CrossRef]

84. Gullette, D. Kumtor: The Litmus Test for Kyrgyzstan's Mining Sector. Zentralasien Analysen 2014, 76, 2-5.

85. Hynes, T.P.; Harrison, J.; Bonitenko, E. The International Scientific Commissions' Assessment of the Impact of the Cyanide Spill at Barskaun, Kyrgyz Republic, 1998. Available online: https:/ / s3.amazonaws. com/cg-raw/cg/final_report_of_the_international_commission_on_th_1998_cyanide_spill.pdf (accessed on 31 March 2018).

86. Institute for War \& Peace Reporting. Toxic Spill Dispute Revived in Kyrgyzstan. Available online: https: / /iwpr.net/global-voices/toxic-spill-dispute-revived-kyrgyzstan (accessed on 16 December 2017).

87. Radio Free Europe/Radio Liberty. Kyrgyzstan: A Commercial Tragedy Revisited. Available online: https: / / www.rferl.org/a/1060387.html (accessed on 31 December 2017).

88. Toralieva, G. Environmental Reporting in Kyrgyzstan. Probl. Post-Communism 2011, 58, 58-66. [CrossRef]

89. Hill, A.F.; Minbaeva, C.K.; Wilson, A.M.; Satylkanov, R. Hydrologic Controls and Water Vulnerabilities in the Naryn River Basin, Kyrgyzstan: A Socio-Hydro Case Study of Water Stressors in Central Asia. Water 2017, 9, 325-341. [CrossRef]

90. Honkonen, T. Challenges of Mining Policy and Regulation in Central Asia: The Case of the Kyrgyz Republic. J. Energy Nat. Resour. Law 2013, 31, 5-32. [CrossRef]

91. Radio Free Europe/Radio Liberty. Many Kyrgyz Fail to Find A Glittering Future in Gold. Available online: https:/ / www.rferl.org/a/why_no_gold_rush_in_kyrgyzstan/24339470.html (accessed on 20 March 2018).

92. Furstenberg, S. Consolidating global governance in nondemocratic countries: Critical reflections on the Extractive Industries Transparency Initiative (EITI) in Kyrgyzstan. Extr. Ind. Soc. 2015, 2, 462-471. [CrossRef]

93. GlacierHub. Protests over Weakening Glacier Protections in Central Asia. Available online: http:/ /glacierhub. org/2017/11/21/protests-weakening-glacier-protections-central-asia/ (accessed on 11 January 2018).

94. Al Jazeera. Conflict continues at Kyrgyzstan's Massive Gold Mine. Available online: http:/ / www.aljazeera. com/indepth/features/2016/01/conflict-continues-kyrgyzstan-massive-gold-160128071445334.html (accessed on 12 January 2018).

95. The Diplomat. Kyrgyzstan's Controversial Gold Mine. Available online: https://thediplomat.com/2015/ 02/kyrgystans-controversial-gold-mine/ (accessed on 11 January 2018). 
96. Robbins, P. Political Ecology; Blackwell: Oxford, UK, 2004.

97. Carnegie Endowment for International Peace. What Was the True Cause of the Kyrgyz Demonstrations? Available online: http:/ / carnegieendowment.org/2012/10/31/what-was-true-cause-of-kyrgyz-demonstrations-pub49853 (accessed on 17 November 2017).

98. The Telegraph. Kyrgyzstan to Decide Fate of Canadian-Owned Gold Mine. Available online: https: / / www.telegraph.co.uk/news/worldnews/asia/kyrgyzstan/9355758/Kyrgyzstan-to-decidefate-of-Canadian-owned-gold-mine.html (accessed on 2 March 2018).

99. Radio Free Europe/Radio Liberty. Hundreds Rally in Jalal-Abad for Release of Opposition Leaders. Available online: https:/ / www.rferl.org/a/hundreds-rally-kyrgyzstan-jalal-abad-freedom-of-detained-oppositionleaders /24729905.html (accessed on 19 December 2017).

100. Radio Free Europe/Radio Liberty. Kyrgyz Opposition Protesters Demand Gold Mine's Nationalization. Available online: https:/ / www.rferl.org/a/kyrgyzstan-kumtor/24966987.html (accessed on 18 December 2017).

101. Ikkevold. Was Kyrgyz Protest Really about Gold Mine or Face Time? Available online: http:/ /www.ikkevold. no/2012/10/was-kyrgyz-protest-really-about-gold-mine-or-face-time/ (accessed on 7 December 2017).

102. Radio Free Europe/Radio Liberty. Questioning the Environmental Cost of Kyrgyzstan's Kumtor Gold Mine. Available online: https: / www.rferl.org/a/kyrgyzstan-kumtor-gold-mine-environmental- /25003485.html (accessed on 16 November 2017).

103. Radio Free Europe/Radio Liberty. Kyrgyz Protesters Again Demand Nationalization of Major Gold Mine. Available online: https:/ / www.rferl.org/a/kyrgyzstan-kumtor-mine-protest/25029473.html (accessed on 18 December 2017).

104. The Jamestown Foundation. Kumtor Gold Mine Protests and Unrest Rock Kyrgyzstan. Available online: https: / jamestown.org/program/kumtor-gold-mine-protests-and-unrest-rock-kyrgyzstan/ (accessed on 2 March 2018).

105. Stratfor Worldview. Kyrgyzstan: Larger Issues behind the Kumtor Protests. Available online: https:/ / worldview. stratfor.com/article/kyrgyzstan-larger-issues-behind-kumtor-protests (accessed on 2 March 2018).

106. Murzakulova, A.; Schoeberlein, J. The invention of legitimacy: Struggles in Kyrgyzstan to craft an effective nation-state ideology. Eur.-Asia Stud. 2009, 61, 1229-1248. [CrossRef]

107. CIA World Factbook. Kyrgyzstan. Available online: https://www.cia.gov/library/publications/the-worldfactbook/geos/kg.html (accessed on 2 March 2018).

108. Kumtor. Centerra Gold Reports of the Status of Negotiations with the Kyrgyz Republic Government on the Restructuring of the Kumtor Project. Available online: https:/ /www.kumtor.kg/en/centerra-gold-reportson-the-status-of-negotiations-with-the-kyrgyz-republic-government-on-the-restructuring-of-the-kumtorproject/ (accessed on 9 January 2018).

109. Reuters. Canada's Centerra Settles Mine Dispute with Kyrgyzstan. Available online: https: / / www.reuters.com/article/centerra-gold-kyrgyzstan/canadas-centerra-settles-mine-dispute-withkyrgyzstan-idUSL4N1LS454 (accessed on 5 January 2017).

110. The New York Times. Political Activism Begins to Take Hold in Kyrgyzstan. Available online: http:/ / www. nytimes.com/2005/12/12/world/asia/political-activism-begins-to-take-hold-in-kyrgyzstan.html (accessed on 3 January 2018).

111. Radio Free Europe/Radio Liberty. Kyrgyz Villagers Block Road to Canadian-Operated Mine. Available online: https: / / www.rferl.org/a /1076331.html (accessed on 31 December 2017).

112. Reuters. Kyrgyz Protesters End Blockade of Gold Mine Road. Available online: https://uk.reuters.com/ article/gold-kyrgyzstan/kyrgyz-protesters-end-blockade-of-gold-mine-road-idUKL5E8H48AG20120604 (accessed on 4 January 2017).

113. Radio Free Europe/Radio Liberty. Rally in Jalal-Abad Demands Release of Kyrgyz Opposition Leaders. Available online: https: / / www.rferl.org/a/rally-jalalabad-demand-release-kyrgyz-opposition-leaders / 24732242.html (accessed on 17 December 2017).

114. Radio Free Europe/Radio Liberty. Kyrgyz Protesters Demand Release of Opposition Leaders. Available online: https: / www.rferl.org/a/kyrgyzstan-ata-jurt-trial-protests/24925095.html (accessed on 17 December 2017).

115. Institute for War \& Peace Reporting. Protests Put Pressure on Kyrgyz Authorities. Available online: http:/ / www.refworld.org/docid/51b596914.html (accessed on 14 January 2018). 
116. Radio Free Europe/Radio Liberty. Protesters Temporarily Block Road in Kyrgyz Mine Dispute. Available online: https: / / www.rferl.org/a/25130755.html (accessed on 17 December 2017).

117. K-News. In the Village of Saruu There Is a Kurultai with the Participation of More than 200 People. Available online: http:/ / knews.kg/2013/10/v-sele-saruu-prohodit-kurultay-s-uchastiem-bolee-200-chelovek/ (accessed on 6 January 2018).

118. AKIpress. Saruu Activists to Protest against Dismissal of Claim Regarding Environmental Damage Caused by Kumtor (Corrected). Available online: https:/ / akipress.com/news:538001 (accessed on 4 January 2018).

119. Hurtado, M.; Lungo, I. Aproximaciones al Movimiento Ambiental en Centroamérica; FLACSO: Ciudad de Guatemala, Guatemala, 2007.

120. Reuters. Mongolia Neo-Nazis Announce a Change of Tack-Pollution Control. Available online: http: / / news.trust.org/ /item/20130702082829-t2gpl? (accessed on 5 March 2018).

(C) 2018 by the author. Licensee MDPI, Basel, Switzerland. This article is an open access article distributed under the terms and conditions of the Creative Commons Attribution (CC BY) license (http://creativecommons.org/licenses/by/4.0/). 